\title{
South African medicinal plant extracts active against influenza $A$ virus
}

Parvaneh Mehrbod ${ }^{1,2} \mathbb{D}$, Muna A. Abdalla ${ }^{3}$, Emmanuel M. Njoya ${ }^{3}$, Aroke S. Ahmed ${ }^{3,4}$, Fatemeh Fotouhi ${ }^{2}$, Behrokh Farahmand ${ }^{2}$, Dorcas A. Gado ${ }^{3}$, Mansoureh Tabatabaian², Olubunmi G. Fasanmi ${ }^{5,6}$, Jacobus N. Eloff ${ }^{3}$, Lyndy J. McGaw ${ }^{3}$ and Folorunso O. Fasina ${ }^{1,7^{*}}$

\begin{abstract}
Background: Influenza infection remains a major health threat for animals and humans which crucially requires effective antiviral remedies. The usage of herbal medications as readily available alternatives for their compatibility with the body and fewer side effects compared to synthetic chemical treatments has become popular globally. The aim of this study was to investigate and screen in vitro anti-influenza activity of extracts of five South African medicinal plants, namely Tabernaemontana ventricosa, Cussonia spicata, Rapanea melanophloeos, Pittosporum viridiflorum and Clerodendrum glabrum, species which are used traditionally for the treatment of several diseases such as inflammatory and respiratory diseases.
\end{abstract}

Methods: Methanol, ethanol (100\% and 30\%), acetone, hot and cold water extracts of the powdered plants leaves were obtained by standard methods. The cytotoxicity was determined by the MTT colorimetric assay on MDCK cells. The concentrations below $\mathrm{CC}_{50}$ values were tested for antiviral activity against influenza A virus (IAV) in different combination treatments. The effect of extracts on viral surface glycoproteins and viral titer were tested by $\mathrm{HI}$ and HA virological assays, respectively.

Results: Based on the applied methods, the most effective results against IAV were obtained from Rapanea melanophloeos methanol leaf extract $\left(\mathrm{EC}_{50}=113.3 \mu \mathrm{g} / \mathrm{ml}\right)$ and Pittosporum viridiflorum methanol, $100 \%$ and $30 \%$ ethanol and acetone leaf extracts ( $E C_{50}$ values $=3.6,3.4,19.2,82.3 \mu \mathrm{g} / \mathrm{ml}$, respectively) in all types of combined treatments especially in pre- and post-penetration combined treatments with highly significant effects against viral titer $(P \leq 0.01)$.

Conclusion: The outcomes offer for the first time a scientific basis for the use of extracts of Rapanea melanophloeos and Pittosporum viridiflorum against IAV. It is worth focusing on the isolation and identification of effective active compounds and elucidating the mechanism of action from these species. However, Tabernaemontana ventricosa, Cussonia spicata and Clerodendrum glabrum leaf extracts were ineffective in vitro in this study.

Keywords: Potential medicinal plants, Influenza A virus, Antiviral activity, South Africa, Rapanea melanophloeos, Pittosporum viridiflorum

\footnotetext{
* Correspondence: folorunso.fasina@fao.org

1 Department of Veterinary Tropical Diseases, University of Pretoria, Pretoria,

South Africa

${ }^{7}$ ECTAD, Food and Agriculture Organization of the United Nations (FAO),

Block P, Level 3, United Nations Complex, UN Avenue, Gigiri, Nairobi, Kenya

Full list of author information is available at the end of the article
}

(c) The Author(s). 2018 Open Access This article is distributed under the terms of the Creative Commons Attribution 4.0 International License (http://creativecommons.org/licenses/by/4.0/), which permits unrestricted use, distribution, and reproduction in any medium, provided you give appropriate credit to the original author(s) and the source, provide a link to the Creative Commons license, and indicate if changes were made. The Creative Commons Public Domain Dedication waiver (http://creativecommons.org/publicdomain/zero/1.0/) applies to the data made available in this article, unless otherwise stated. 


\section{Background}

Three types of influenza viruses - A, B and C - are classified under the family Orthomyxoviridae. Types $\mathrm{A}$ and $\mathrm{B}$ are considered to be predominant causes of human and animal infections [1]. However, influenza A virus causes the most severe respiratory diseases which result in considerable morbidity and sometimes high mortality [2]. The common unfavorable symptoms of flu which start normally one to two days after infection are chills, high fever, watering and sore eyes, and rash [3, 4]. Influenza epidemics and pandemics have occurred in the past. The development of vaccines and conventional antiviral agents and their effectiveness against influenza viruses has been limited. Moreover, side effects of antiviral resistance during therapy may affect the central nervous system and the gastrointestinal tract, and have been disappointing mainly due to antigenic shifts and drifts of the virus [5]. Therefore, influenza infections still remain a major cause of mortality and morbidity in humans and animals [6].

Oseltamivir and zanamivir are recommended for both treatment and prophylaxis of influenza to prevent the release of viral particles by blocking neuraminidase. Amantadine and rimantadine have also been used against influenza to inhibit penetration/un-coating of the virus by inhibiting ion-channel M2 protein [7-9]. Clinical efficacy of all these drugs is ambiguous [10] and several cases of drug resistance have been reported [7]. It is well known that medicinal plants have been used all over the world, even in regions with advanced healthcare systems [11], and numerous traditional cultures still rely on indigenous medicinal plants for their primary health care needs [12]. Medicinal plants form an integral part of primary health care in different parts of the world [13-16], and are becoming increasingly popular in modern society as natural alternatives to synthetic medicines [17]. It is possible that the active medicinal plants do not necessarily contain antimicrobial agents, but act by stimulating the victim's immune system. Traditional herbs are generally cheaper, accessible or readily available and more culturally acceptable. Furthermore, some synthetic drugs cause undesirable side effects $[17,18]$. Consequently, a research focus on traditional herbs as complementary therapies or preventive medicine is becoming more attractive.

South Africa is a country which has a strong history of traditional healing, and hosts a wide biodiversity of approximately 30,000 flowering plant species [19], accounting for almost $10 \%$ of the world's higher plant species [20]. Phytochemical studies of medicinal plants have revealed different classes of natural compounds with several pharmacological properties. The various uses of plants include treatment of numerous diseases and life-threatening conditions such as viral diseases and cancer [21]. Medicinal plants have been used to treat influenza disease for decades [1, 22-25]. In our endeavor to discover active plants against IVA, plants were selected based on published traditional indications and pharmacological properties against various diseases and infections. Examples are the bark of Tabernaemontana ventricosa tree, which is used to palliate fever and treat wounds and sore eyes. Moreover its wood is suitable for planks and insect-proof material [26]. The ethanolic and aqueous leaf extracts of Clerodendrum glabrum have been tested to treat inflammatory diseases [27], and they have anthelmintic, anti-amoebic and antibacterial activities [28]. Cussonia spicata bark, roots and leaf extracts have been used for treatment of wounds and they had antibacterial, antiinflammatory [29], in vitro anthelmintic [30], and in vitro antiplasmodial activities [31]. The leaf and bark extracts of Pittosporum viridiflorum had antioxidant activity in HIVinfected patients and could serve as free radical inhibitors [32]. Rapanea melanophloeos bark, fruit and leaves are used traditionally for different diseases such as disorders of the stomach, nervous system and respiratory troubles [33]. To the best of our knowledge, the South African medicinal plants under study have never been studied for antiviral activity against influenza A virus. The overall objective of this study was therefore to evaluate and determine the potential activity of the crude extracts of these five medicinal plants against influenza A virus (IAV) infection using the hemagglutination (HA) assay and hemagglutination inhibition (HI) assays.

\section{Methods}

\section{Preparation of plant extracts}

Plants were collected from the Pretoria National Botanical Garden (NBG), South Africa in the summer months. One of the authors (Lyndy J. McGaw), a botanist identified the plant material and voucher specimens were deposited in the HGWJ Schweickerdt Herbarium (PRU), University of Pretoria, South Africa. The identities of the plants were confirmed by herbarium staff. The leaves of plants were air-dried in the shade at room temperature in a wellventilated room before grinding to fine powder using a Macsalab mill (Model 200 LAB) Eriez, Bramley. Separate aliquots of ground material were extracted (10 ml:1 v:m) using methanol, $30 \%$ and $100 \%$ ethanol, acetone and water (hot at $40^{\circ} \mathrm{C}$, and cold). Each extract was dried under low temperature before reconstituting the extracts at $100 \mathrm{mg} / \mathrm{ml}$ in DMSO. The extracts were numbered and stored in a cool environment. The extracts numbers were numbered as follows: 1: Pittosporum viridiflorum, aqueous hot, 2: Pittosporum viridiflorum, aqueous cold, 3: Pittosporum viridiflorum, acetone, 4: Pittosporum viridiflorum, 30\% ethanol, 5: Pittosporum viridiflorum, 100\% ethanol, 6: Pittosporum viridiflorum, methanol, 7: Cussonia spicata, aqueous hot, 8: Cussonia spicata, 
aqueous cold, 9: Cussonia spicata, acetone, 10: Cussonia spicata, 30\% ethanol, 11: Cussonia spicata, 100\% ethanol, 12: Cussonia spicata, methanol, 13: Rapanea melanophloeos, methanol, 14: Tabernaemontana ventricosa, methanol and 15: Clerodendrum glabrum, methanol.

\section{Cell culture and influenza virus propagation}

Madin Darby Canine Kidney (MDCK) cells purchased from ATCC (CCL-34 ${ }^{\mathrm{Tm}}$ ) were grown in Dulbecco's Modified Eagle's Medium (DMEM) (Mediatech Cellgro, USA), supplemented with 10\% Fetal Bovine Serum (FBS) (PAA, Austria) and 1\% Pen/Strep (Mediatech Cellgro, USA) at $37{ }^{\circ} \mathrm{C}$ in a humidified incubator. The influenza vaccine strain, A/Puerto Rico/8/1934 (H1N1) (ATCC VR-1469 ${ }^{\mathrm{mm}}$ ) was obtained from the Influenza Department, Pasteur Institute of Iran. It was propagated in MDCK cells. DMEM supplemented with $1 \mu \mathrm{g} / \mathrm{ml}$ of Trypsin-TPCK (Tosylamide Phenylethyl Chloromethyl Keton-treated Trypsin) (Sigma, USA) without FBS was used as maintenance medium during antiviral experiments. Cell culture infectious dose $50\left(\mathrm{CCID}_{50}\right)$ in combination with the hemagglutination assay were used to measure the virus infectivity dose [34, 35].

\section{Cytotoxicity assay}

MDCK cells were incubated in 96-well microplates (Nunc, Denmark) $\left(3 \times 10^{4}\right.$ cell/well) for $24 \mathrm{~h}$ at $37{ }^{\circ} \mathrm{C}$. Serial two-fold dilutions of the extracts in complete medium were added to the semi-confluent cells in triplicate and incubated for $48 \mathrm{~h}$. The colorimetric MTT assay was performed according to Mosmann [36] modified by Mehrbod et al. [37]. Briefly, the culture medium was removed and MTT 1X [3-(4,5-dimethyl-2-thiazolyl)2,5-diphenyl-2H-tetrazolium bromide; Sigma, USA] in $100 \mu \mathrm{l}$ in PBS was added to each well. Following 3-4 h incubation at $37{ }^{\circ} \mathrm{C}$, the medium containing MTT was removed and DMSO $(100 \mu \mathrm{l})$ was added to each well to dissolve the formazan crystals to release purple formazan color. The absorbance of the color in the solution was obtained at $570 \mathrm{~nm}$ with a microplate reader (BioTek EL 800, US) to calculate viability of the cells using the following formula: (mean Optical Density (OD) of treated cells/mean OD of control cells) $\times 100$. The $50 \%$ cytotoxic concentration $\left(\mathrm{CC}_{50}\right)$ which causes visible morphological changes in $50 \%$ of the cells with respect to the control cell and effective concentration $\left(\mathrm{EC}_{50}\right)$ which is the concentration required to achieve $50 \%$ protection against virus induced cytopathic effect were also calculated using MTT data analyzing by SPSS software. The cells without extract exposure served as negative controls. DMSO as a vehicle control with maximum $0.5 \%$ concentration was tested as well.

\section{Selectivity index}

The relative safety of the extracts was obtained by calculating the selectivity index (SI). It is calculated by dividing $\mathrm{CC}_{50}$ by $\mathrm{EC}_{50}$ in the same units. Selectivity index values higher than 3 indicate potentially safe antiviral activity of the extract [38].

\section{Antiviral assay}

During antiviral evaluations, media supplemented with FBS was removed and the cells were washed with PBS then treated as needed. Influenza virus $\left(100 \mathrm{TCID}_{50} / 0\right.$. $1 \mathrm{ml}$ ) was added to the cells in different combination treatments. It was mixed with the extracts $\mathrm{EC}_{50}$ for $30 \mathrm{~min}$, then added to the cells and incubated for $1 \mathrm{~h}$ at $37{ }^{\circ} \mathrm{C}$ (co-penetration procedure). In two other ways, the virus was added to the cells after and/or before the extracts in the span of $1 \mathrm{~h}$ (pre-penetration and post-penetration procedures). Following $1 \mathrm{~h}$ incubation, unabsorbed viruses were washed and TPCK-containing medium $(1 \mu \mathrm{g} / \mathrm{ml})$ was added. Following $48 \mathrm{~h}$ incubation at $37{ }^{\circ} \mathrm{C}$, viabilities of the cells were evaluated by MTT assay as described earlier. Concurrently, the virus titer was determined by testing the cell supernatants using the HA assay [37]. Amantadine hydrochloride $(98.5 \mu \mathrm{g} / \mathrm{ml})$ and oseltamivir carboxylate (394.25 $\mu \mathrm{g} / \mathrm{ml})$ (Sigma, Saint Louis, Missouri, USA) were tested in parallel as control antiviral groups. The cells without extract exposure served as negative controls. DMSO as a vehicle control with maximum $0.5 \%$ concentration was tested as well.

\section{Cellular percentage of protection}

The percentage of protection of extracts was calculated using SPSS from the MTT results of mock-infected and infected cells after $48 \mathrm{~h}$ exposure, by using the following formula: Percentage of protection $=[(\mathrm{ODT}) \mathrm{V}-(\mathrm{ODC}) \mathrm{V}] /$ [(ODC)M - (ODC) V] $\times 100$ where $(\mathrm{ODT}) \mathrm{V},(\mathrm{ODC}) \mathrm{V}$ and (ODC)M represent the absorbance of the treated sample, the virus-infected control (no compound) and the negative control (mock), respectively [39].

\section{Hemagglutination assay (HA)}

HA activity can be visualized upon mixing virus dilutions with washed chicken erythrocytes in microtitre plates. To evaluate the presence of the virus in cell culture, in either treated or non-treated cells, double serial dilutions of the culture media were added to U-bottom 96-well microplates. Washed chicken red blood cells (cRBCs) (0.5\%) were added to each well. The assay was carried out as described previously by Hirst [40] and modified by Mehrbod et al. [37]. HA units were calculated as the reciprocal of the highest dilution giving complete agglutination. Precipitation of the RBCs demonstrates the absence of the virus while hemagglutination and diffuse lattice formation indicates the presence of the virus. 


\section{Hemagglutination inhibition assay (HI)}

The lowest amounts of virus particles that can agglutinate the chicken erythrocytes (4HA unit) were used to investigate the inhibitory effect of extracts on the hemagglutinating activity. Briefly, the extracts were serially diluted 2 -fold with a concentration range of $10-0$. $04 \mathrm{mg} / \mathrm{ml}(25 \mu \mathrm{l} /$ well $)$. From the virus stock $4 \mathrm{HA}$ unit was prepared and added to all wells $(25 \mu \mathrm{l} /$ well $)$. After pre-incubation of $45 \mathrm{~min}$ at room temperature, chicken erythrocytes $(50 \mu \mathrm{l} /$ well $)$ were added to the solution and after $1 \mathrm{~h}$ the physical interaction between extracts and virus surface HA glycoprotein was read by the agglutination inhibition pattern.

\section{Phytochemical pre-screening}

Qualitative phytochemical pre-screening was performed to allow the detection of potentially interesting compounds at the earliest stages of separation. A spot of the crude extracts was developed on TLC plates and separately eluted using CEF [Chloroform: Ethyl acetate: Formic acid (90:10:1)] and EMW [Ethyl acetate: Methanol: Water (40:4.5:4)] solvent systems [41]. The zones on the developed TLC plates were visualized under UV light $(254$ and $365 \mathrm{~nm})$ and further localized by exposure to a vanillin-sulphuric acid spray reagent.

\section{Statistical analysis}

The data expressed as mean \pm SD was analyzed by oneway analysis of variance (ANOVA) and General Linear Model (GLM) (SPSS 18.0) LSD and Duncan post-hoc tests. Sample values with $p \leq 0.05$ and $p \leq 0.01$ were considered statistically significant and highly significant, respectively.

\section{Results}

In this study, methanol, ethanol, acetone and hot and cold aqueous extracts of five selected plant species were tested for their antiviral efficacy against IAV. The cytotoxicity of the extracts was tested to determine the non-toxic concentrations for cell viability prior to antiviral assay. With different extracts and virus combined treatments, the antiviral activity varied with the different extracts of the same plant as determined by the HA assay. The profile of the five medicinal plants used in this study is listed in Table 1.

\section{Cytotoxicity of plant extracts on MDCK cells and their selectivity indices against virus}

In this study, the acetone, methanol, ethanol, hot and cold aqueous extracts of five selected medicinal plants were differentially cytotoxic to MDCK cells and the appropriate concentrations were determined for cell viability and further assays. The medicinal plant Rapanea melanophloeos had the highest $\mathrm{CC}_{50}$ value of $227 \pm 13.6 \mu \mathrm{g} / \mathrm{ml}$ followed by Clerodendrum glabrum with $221 \pm 34.9 \mu \mathrm{g} /$ $\mathrm{ml}$. The lowest $\mathrm{CC}_{50}$ value $(0.1 \pm 0.07 \mu \mathrm{g} / \mathrm{ml})$ was obtained with Tabernaemontana ventricosa (Table 2). The results for $\mathrm{CC}_{50}$ were broadly different for different extracts (Table 2). The $\mathrm{EC}_{50}$ of the extracts were calculated from the MTT results by one-way ANOVA analysis and compared to the negative control with no significant effects on cell viability. These results were obtained from the extract concentrations that reduced viral titer and maintenance of cell viability (Table 2). The selectivity index values of the extracts were calculated with the highest SI value of 8 obtained with Cussonia spicata and lowest SI value of 2 obtained with Pittosporum viridiflorum, Rapanea melanophloeos, Tabernaemontana ventricosa and Clerodendrum glabrum. The $\mathrm{CC}_{50}$ values for Amantadine hydrochloride and oseltamivir carboxylate in MDCK cells were calculated as $197 \mu \mathrm{g} / \mathrm{ml}$ and $788 \mu \mathrm{g} / \mathrm{ml}$, respectively. Concentrations of $1510.0 \mathrm{mg} / \mathrm{ml}$ and $3120.0 \mathrm{mg} / \mathrm{ml}$ were used as $\mathrm{EC}_{50}$ of amantadine and oseltamivir, respectively.

\section{Inhibitory effect of plant extracts on influenza A virus}

Different crude extracts were tested in an in vitro microinhibition screening assay to determine antiviral activity against influenza A virus. Antiviral activity of the crude extracts of the selected plants was analyzed based on the $\log _{10}$ HA titer (Table 3) and Log HA decrement (Fig. 1). Extracts from two species Pittosporum viridiflorum and

Table 1 Profile of the five medicinal plants used in this study

\begin{tabular}{|c|c|c|c|c|}
\hline Botanical name & Family & Local Name & Plant part used & Voucher number \\
\hline $\begin{array}{l}\text { Tabernaemontana ventricosa } \\
\text { Hochst. ex. A.DC. }\end{array}$ & Apocynaceae & Bospaddaboom & leaf & PRU 120680 \\
\hline $\begin{array}{l}\text { Cussonia spicata } \\
\text { Thunb. }\end{array}$ & Araliaceae & Kiepersol & leaf & PRU 115683 \\
\hline $\begin{array}{l}\text { Rapanea melanophloeos } \\
\text { (L.) Mez }\end{array}$ & Myrsinaceae & Kaapseboekenhout, boekenhout & leaf & PRU 120670 \\
\hline $\begin{array}{l}\text { Pittosporum viridiflorum } \\
\text { Sims }\end{array}$ & Pittosporaceae & Kasuur & leaf & PRU 120025 \\
\hline $\begin{array}{l}\text { Clerodendrum glabrum } \\
\text { E.Mey. var. glabrum }\end{array}$ & Verbenaceae & Tontelhout & leaf & PRU 114809 \\
\hline
\end{tabular}


Table $2 \mathrm{CC}_{50}, \mathrm{EC}_{50}$ and SI of the extracts

\begin{tabular}{|c|c|c|c|}
\hline Plant name and number ${ }^{a}$ & Extract type & $\begin{array}{l}\mathrm{CC}_{50}(\mu \mathrm{g} / \mathrm{ml}) \\
(\mathrm{mean} \pm \mathrm{SD})\end{array}$ & $\mathrm{EC}_{50}(\mu \mathrm{g} / \mathrm{ml})$ \\
\hline Pittosporum viridiflorum, 2 & Cold water & $129 \pm 12.6$ & 32.2 \\
\hline Pittosporum viridiflorum, 3 & Acetone & $165 \pm 25.2$ & 82.3 \\
\hline Pittosporum viridiflorum, 4 & $30 \%$ ethanol & $77 \pm 24.8$ & 19.2 \\
\hline Pittosporum viridiflorum, 5 & $100 \%$ ethanol & $7 \pm 5.8$ & 3.4 \\
\hline Pittosporum viridiflorum, 6 & Methanol & $15 \pm 9.3$ & 3.6 \\
\hline Cussonia spicata, 9 & Acetone & $108 \pm 2.4$ & 13.5 \\
\hline Cussonia spicata, 11 & $100 \%$ ethanol & $39 \pm 12.6$ & 4.8 \\
\hline Cussonia spicata, 12 & Methanol & $117 \pm 11.5$ & 14.6 \\
\hline Rapanea melanophloeos, 13 & Methanol & $227 \pm 13.6$ & 113.3 \\
\hline Tabernaemontana ventricosa, 14 & Methanol & $0.1 \pm 0.07$ & 0.05 \\
\hline Clerodendrum glabrum, 15 & Methanol & $221 \pm 34.9$ & 110.4 \\
\hline
\end{tabular}

$C C_{50} 50 \%$ cytotoxic concentration, $E C_{50} 50 \%$ effective concentration, S/ Selectivity Index

${ }^{a}$ Number refers to the plants numbering throughout the manuscript

2: Cold water extract of Pittosporum viridiflorum; 3: Acetone extracts of Pittosporum viridiflorum; 4: $30 \%$ ethanolic extract of Pittosporum viridiflorum;; 5: $100 \%$ ethanolic extract of Pittosporum viridiflorum; 6: Methanolic extract of Pittosporum viridiflorum; 9: Acetone extract of Cussonia spicata; 11: 100\% ethanolic extract of Cussonia spicata; 12: Methanolic extract of Cussonia spicata; 13: Methanolic extract of Rapanea melanophloeos; 14: Methanolic extract of Tabernaemontana ventricosa; 15: Methanolic extract of Clerodendrum glabrum.

Rapanea melanophloeos, had remarkable and promising antiviral activity against IAV. The averages of 7.4 and 5 logs HA decrements were observed in all types of combined treatments of Rapanea melanophloeos and Pittosporum viridiflorum, respectively. $\log _{10}$ HA titer from HA assay in combined treatments showed that these two plant extracts applied the most significant activity on the virus titer especially in pre- and post-penetration procedures for Pittosporum viridiflorum, but in all types of combined treatments for Rapanea melanophloeos.

\section{Cell viability in combined treatments}

The results of the MTT assay for antiviral activity of the extracts against IAV revealed that treatments exposed to different types of combined treatments of extracts $\mathrm{EC}_{50}$ and virus $100 \mathrm{CCID}_{50}$ had highly significant increment in ODs compared to the virusinoculated cells alone $(P \leq 0.01)$. Exposure of the cells to amantadine and oseltamivir $\mathrm{EC}_{50}$ combined with the virus resulted in high cell viability $(P \leq 0.01)$ (Table 4).

Table $3 \log _{10}$ HA titer from HA assay in combined treatments with virus compared to virus control group

\begin{tabular}{|c|c|c|c|c|c|}
\hline & \multirow[t]{2}{*}{ Treatment } & \multirow[t]{2}{*}{ Extract type } & \multicolumn{3}{|c|}{ Log HA $($ mean $\pm S D)$} \\
\hline & & & Co-pen & Pre-pen & Post-pen \\
\hline \multirow[t]{13}{*}{ Combined treatments } & Pittosporum viridiflorum, 2 & Cold water & $1.51 \pm 1.17$ & $1.20 \pm 0.93^{* *}$ & $1.30 \pm 1.02^{*}$ \\
\hline & Pittosporum viridiflorum, 3 & Acetone & $0.90 \pm 0.97^{* *}$ & $1.00 \pm 1.12^{* *}$ & $1.00 \pm 0.82^{* *}$ \\
\hline & Pittosporum viridiflorum, 4 & $30 \%$ ethanol & $1.61 \pm 1.24$ & $0.60 \pm 0.93^{* *}$ & $0.60 \pm 0.93^{* *}$ \\
\hline & Pittosporum viridiflorum, 5 & $100 \%$ ethanol & $0.90 \pm 1.17^{* *}$ & $1.00 \pm 1.12^{* *}$ & $1.00 \pm 1.12^{* *}$ \\
\hline & Pittosporum viridiflorum, 6 & Methanol & $1.51 \pm 1.17$ & $1.30 \pm 1.02^{*}$ & $1.00 \pm 0.78^{* *}$ \\
\hline & Cussonia spicata, 9 & Acetone & $1.40 \pm 1.09$ & $1.30 \pm 1.02^{*}$ & $1.51 \pm 1.17$ \\
\hline & Cussonia spicata, 11 & $100 \%$ ethanol & $1.61 \pm 1.24$ & $1.81 \pm 0.47$ & $1.61 \pm 1.24$ \\
\hline & Cussonia spicata, 12 & Methanol & $1.61 \pm 1.24$ & $2.01 \pm 0.41$ & $1.61 \pm 1.02$ \\
\hline & Rapanea melanophloeos, 13 & Methanol & $0.00 \pm 0.00^{* *}$ & $0.60 \pm 0.93^{* *}$ & $0.30 \pm 0.00^{* *}$ \\
\hline & Tabernaemontana ventricosa, 14 & Methanol & $2.31 \pm 0.16$ & $2.21 \pm 0.16$ & $2.31 \pm 0.16$ \\
\hline & Clerodendrum glabrum, 15 & Methanol & $1.40 \pm 0.78$ & $1.91 \pm 0.56$ & $1.51 \pm 1.17$ \\
\hline & Amantadine hydrochloride & - & $0.60 \pm 0.93^{* *}$ & $0.80 \pm 0.82^{* *}$ & $0.90 \pm 0.97^{* *}$ \\
\hline & Oseltamivir carboxylate & - & $0.60 \pm 0.93^{* *}$ & $0.60 \pm 0.93^{* *}$ & $0.70 \pm 1.09^{* *}$ \\
\hline No extract treatment & Influenza virus & - & $2.51 \pm 0.31$ & $2.51 \pm 0.31$ & $2.51 \pm 0.31$ \\
\hline
\end{tabular}

Data presented as mean \pm SD are averages of 3 independent HA titration. ${ }^{*},{ }^{*}$ : Significantly and highly significantly different from values obtained for extract-treated samples compared to virus inoculated untreated sample $(P \leq 0.05 \& P \leq 0.01)$ analyzed by SPSS, LSD post-hoc test 


\section{Log HA decrement}

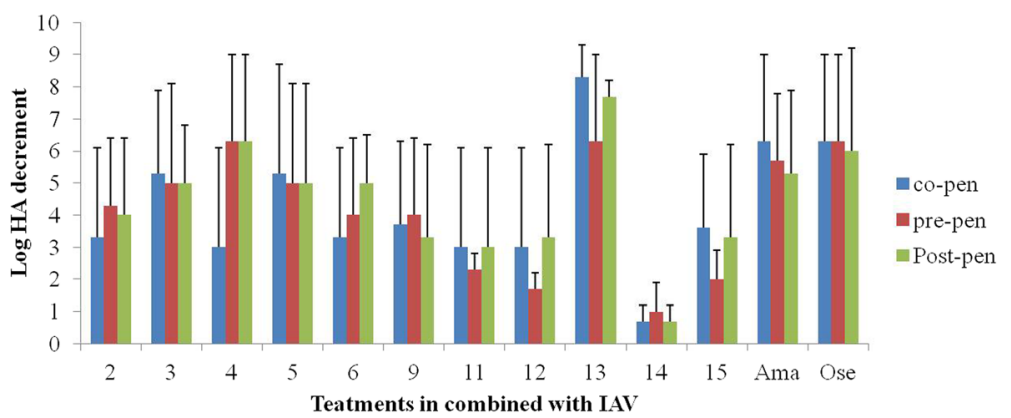

Fig. $1 \log _{10}$ HA decrement obtained from HA assay. Data presented as mean \pm SD are averages of 3 independent HA titrations. Ama: Amantadine and Ose: Oseltamivir. The negative controls have no virus added and remained at zero value through-out the study

\section{Cellular percentage of protection}

The ODs were also analyzed to examine the percentage of extract protection on cell viability against the virus infectivity assay in combined treatments. Data are recorded in Table 5. Extract numbers 3, 9, 13 and 15 had the highest consistent percentage of protection in all types of combined treatments.

\section{Hemagglutination-inhibition}

The current study indicated that treatment of IAV with the extracts reduced the hemagglutination activity of the virus, which may result from the physical interaction of the extracts with virus hemagglutinin. All plant extracts in different dilutions, even after repeating the assay twice, did not show any inhibition of RBC agglutination.
This can be attributed to arguing against physical HA interaction of the extract ingredients with RBC.

\section{Phytochemical pre-screening}

Several different compounds were present in the TLC of the crude extracts based on the different colors with vanillin-sulphuric acid spray reagent. Further purification will be performed to isolate the active constituents.

\section{Discussion}

In the current report antiviral activities of some traditionally used medicinal plants were investigated for inhibitory effects against influenza A virus infection. Previous reports have defined quality standards for antiviral evaluation: a stringent endpoint of $\mathrm{EC}_{50}$ values less than $100 \mu \mathrm{g} / \mathrm{ml}$, including SI values of more than 3 are

Table 4 Cell viabilities from MTT assay in combined treatments with virus compared to virus control group

\begin{tabular}{|c|c|c|c|c|}
\hline \multirow[t]{2}{*}{ Treatment } & \multirow[t]{2}{*}{ Extract type } & \multicolumn{3}{|l|}{$\begin{array}{l}\text { Cell viability } \\
\text { (mean } \pm \text { SD) }\end{array}$} \\
\hline & & Co-pen & Pre-pen & Post-pen \\
\hline Pittosporum viridiflorum, 2 & Cold water & $0.59 \pm 0.11^{* *}$ & $0.70 \pm 0.18^{* *}$ & $0.65 \pm 0.15^{* *}$ \\
\hline Pittosporum viridiflorum, 3 & Acetone & $0.85 \pm 0.17^{* *}$ & $0.85 \pm 0.23^{* *}$ & $0.84 \pm 0.18^{* *}$ \\
\hline Pittosporum viridiflorum, 4 & $30 \%$ ethanol & $0.57 \pm 0.06^{* *}$ & $0.79 \pm 0.11^{* *}$ & $0.70 \pm 0.16^{* *}$ \\
\hline Pittosporum viridiflorum, 5 & $100 \%$ ethanol & $0.54 \pm 0.07^{* *}$ & $0.56 \pm 0.10^{* *}$ & $0.48 \pm 0.07^{* *}$ \\
\hline Pittosporum viridiflorum, 6 & Methanol & $0.49 \pm 0.07^{* *}$ & $0.76 \pm 0.10^{* *}$ & $0.74 \pm 0.16^{* *}$ \\
\hline Cussonia spicata, 9 & Acetone & $0.79 \pm 0.11^{* *}$ & $0.90 \pm 0.09^{* *}$ & $0.76 \pm 0.10^{* *}$ \\
\hline Cussonia spicata, 11 & 100\% ethanol & $0.59 \pm 0.05^{* *}$ & $0.81 \pm 0.16^{* *}$ & $0.57 \pm 0.10^{* *}$ \\
\hline Cussonia spicata, 12 & Methanol & $0.53 \pm 0.04^{* *}$ & $0.55 \pm 0.21^{* *}$ & $0.56 \pm 0.14^{* *}$ \\
\hline Rapanea melanophloeos, 13 & Methanol & $0.75 \pm 0.23^{* *}$ & $0.83 \pm 0.16^{* *}$ & $0.80 \pm 0.23^{* *}$ \\
\hline Tabernaemontana ventricosa, 14 & Methanol & $0.60 \pm 0.12^{* *}$ & $0.63 \pm 0.21^{* *}$ & $0.67 \pm 0.17^{* *}$ \\
\hline Clerodendrum glabrum, 15 & Methanol & $0.71 \pm 0.25^{* *}$ & $0.80 \pm 0.20^{* *}$ & $0.78 \pm 0.25^{* *}$ \\
\hline Amantadine hydrochloride & - & $0.79 \pm 0.13^{* *}$ & $0.75 \pm 0.09^{* *}$ & $0.71 \pm 0.14^{* *}$ \\
\hline Oseltamivir carboxylate & - & $0.83 \pm 0.16^{* *}$ & $0.83 \pm 0.18^{* *}$ & $0.69 \pm 0.14^{* *}$ \\
\hline Influenza virus & - & $0.20 \pm 0.05$ & $0.20 \pm 0.05$ & $0.20 \pm 0.05$ \\
\hline
\end{tabular}

Data presented as mean \pm SD are averages of 4 independent MTT assays. **: highly significantly different from values obtained for drugs-treated samples compared to untreated sample $(P \leq 0.01)$ analyzed by SPSS, LSD post-hoc test 
Table 5 Cellular percentage of protection in combined treatments with virus compared to control groups

\begin{tabular}{|c|c|c|c|c|}
\hline \multirow[t]{2}{*}{ Treatment } & \multirow[t]{2}{*}{ Extract type } & \multicolumn{3}{|c|}{$\begin{array}{l}\text { Percentage of protection } \\
(\text { mean } \pm \text { SD) }\end{array}$} \\
\hline & & Co-pen & Pre-pen & Post-pen \\
\hline Pittosporum viridiflorum, 2 & Cold water & $49.26 \pm 10.78^{\mathrm{ab}}$ & $64.19 \pm 28.68^{\mathrm{bcd}}$ & $56.61 \pm 20.33^{\mathrm{bc}}$ \\
\hline Pittosporum viridiflorum, 3 & Acetone & $81.71 \pm 14.37^{e}$ & $81.69 \pm 23.00^{\text {de }}$ & $79.67 \pm 13.33^{d}$ \\
\hline Pittosporum viridiflorum, 4 & $30 \%$ ethanol & $47.29 \pm 9.44^{\mathrm{ab}}$ & $75.09 \pm 17.48^{\text {cde }}$ & $63.84 \pm 25.29^{\mathrm{bcd}}$ \\
\hline Pittosporum viridiflorum, 5 & $100 \%$ ethanol & $43.97 \pm 18.11^{\mathrm{a}}$ & $46.29 \pm 12.70^{\mathrm{ab}}$ & $35.60 \pm 14.63^{\mathrm{a}}$ \\
\hline Pittosporum viridiflorum, 6 & Methanol & $38.27 \pm 18.56^{a}$ & $71.45 \pm 18.57^{\text {cde }}$ & $68.54 \pm 22.62^{\mathrm{cd}}$ \\
\hline Cussonia spicata, 9 & Acetone & $74.87 \pm 13.14^{\mathrm{de}}$ & $88.45 \pm 17.11^{\mathrm{e}}$ & $70.34 \pm 6.59^{c d}$ \\
\hline Cussonia spicata, 11 & $100 \%$ ethanol & $50.50 \pm 18.12^{\mathrm{ab}}$ & $76.68 \pm 12.20^{\mathrm{de}}$ & $47.22 \pm 6.28^{\mathrm{ab}}$ \\
\hline Cussonia spicata, 12 & Methanol & $41.94 \pm 10.49^{a}$ & $42.54 \pm 17.52^{\mathrm{a}}$ & $45.69 \pm 12.00^{\mathrm{ab}}$ \\
\hline Rapanea melanophloeos, 13 & Methanol & $68.75 \pm 18.78^{\text {cde }}$ & $78.75 \pm 9.03^{\text {de }}$ & $74.39 \pm 19.81^{c d}$ \\
\hline Tabernaemontana ventricosa, 14 & Methanol & $53.13 \pm 26.48^{\mathrm{abc}}$ & $55.90 \pm 30.94^{\mathrm{abc}}$ & $59.65 \pm 22.68^{b c d}$ \\
\hline Clerodendrum glabrum, 15 & Methanol & $63.63 \pm 19.51^{\mathrm{bcd}}$ & $74.22 \pm 15.10^{\text {cde }}$ & $71.87 \pm 22.00^{c d}$ \\
\hline Amantadine hydrochloride & - & $73.94 \pm 9.94^{\mathrm{de}}$ & $69.88 \pm 10.02^{\text {cde }}$ & $64.50 \pm 10.29^{\mathrm{bcd}}$ \\
\hline Oseltamivir carboxylate & - & $79.44 \pm 9.89^{\text {de }}$ & $79.26 \pm 12.85^{\mathrm{de}}$ & $61.37 \pm 11.71^{\mathrm{bcd}}$ \\
\hline
\end{tabular}

Data presented as mean \pm SD are averages of 4 independent tests. Different letters show significant differences in each column (Duncan Grouping)

the defined standard for antiviral efficacy of natural products [38, 42]. Medicinal plants have progressively been explored as suitable alternative sources of antiviral agents [1,43-45] and research efforts continue. After applying the different treatments and evaluation of the viral HA titer, all extracts were highly significantly protective on the cell viability in all types of combined treatments $(P \leq 0.01)$. The methanol extract of Rapanea melanophloeos and different extracts of Pittosporum viridiflorum afforded the most effective HA results against IAV $(P \leq 0.01)$. The crude extracts of Cussonia spicata, Tabernaemontana ventricosa and Clerodendrum glabrum, which had good SI values (more than 3), were weakly active against IAV with no significant decrease in IAV HA titer $(P \geq 0.05)$. Amantadine hydrochloride and oseltamivir carboxylate displayed a significant eliminating effect on the HA titer in comparison with the extracts of Rapanea melanophloeos and Pittosporum viridiflorum and they were better than most other extracts tested in this study. Regarding the $\log _{10}$ HA decrement, the most effective extracts at the first level were extracts of Rapanea melanophloeos with an average of $7.4 \mathrm{log}$ decrement and Pittosporum viridiflorum with an average of 5 $\log$ decrements. The lowest effect belonged to Tabernaemontana ventricosa methanol extract with 0.8 log decrement. The known conventional antiviral drugs amantadine and oseltamivir are promisingly effective agents, but growing resistance of viruses has created a significant challenge $[46,47]$ and it is recommended to focus on new alternatives especially those of natural origin. By following the HI assay it was confirmed that none of the extracts showed physical interaction with virus HA surface glycoproteins.
Moreover, by GLM analysis of the results, estimated marginal means of all the respective values were calculated for different exposure ways (combined treatment) which confirmed all the outcomes. The data are shown in Additional file 1: Figure S1, Additional file 2: Figure S2, Additional file 3: Figure S3 and Additional file 4: Figure S4.

Several studies have demonstrated that influenza infections lead to uncontrolled elevations of pro-inflammatory cytokines, making this infection a strong risk factor for severe complications which could be terminal [48-51]. Therefore, effective alternative therapeutics to conventional antiviral drugs can be based on anti-inflammatory and immunomodulatory agents [52]. The ethanolic and aqueous extracts of Clerodendrum glabrum have been tested for efficacy in treating inflammatory diseases [27]. Additionally, the leaf extract of this plant exhibited anthelmintic, anti-amoebic and antibacterial activity [28]. The leaf extract of Clerodendrum glabrum, which is high in flavonoid content, is used for cough, cold, sore throat and chest complaints. The local Zulu people in South Africa take leaf infusions for cough and fever [53, 54]. Leaf infusions are also taken by the Vhavenda for cold, sore throat, chest complaints and as an insect repellent [54]. Von Koenen [55] reported that the Zulu make an extract of the root and it is suggested that this extract is used to assist fever and cough. It was also reported to have antiinflammatory, in vitro anthelmintic [30] and other activities against intestinal parasites and diabetes [53, 54], Plasmodium falciparum strain D10 [56], Gram-positive and Gram-negative bacteria [57] and fungal pathogens [58]. The medicinal plant Cussonia spicata had antiviral activity by causing a $2 \log$ reduction in feline herspesvirus 
type 1 [59]. Therefore, the above mentioned plant species might be promising alternatives to decrease the unfavorable effects of flu.

Influenza is a viral pathogen that imposes a burden of central nervous system (CNS) disease as well. An increasing incidence of influenza-associated encephalitis has been reported $[60,61]$. It is important to notice that oxygen and nitrogen free radicals are also involved in pathogenesis of influenza virus infection [62]. Oxygen radicals and nitric oxide are over-generated in a variety of microbial infections. They cause tissue injury and mutagenesis through oxidation and nitration of various bio-molecules. The above-mentioned scenario may be explained if plants with antioxidant potency possess antiviral activity as well. This is in agreement with the findings of the current study, where the antiviral medicinal plant Pittosporum viridiflorum investigated in this study previously had antioxidant and free radical inhibition properties [32]. It also has been used traditionally in the treatment of opportunistic fungal infections in HIV/ AIDS patients in the Eastern Cape Province, South Africa [63]. Infusions of Pittosporum viridiflorum leaves have been used to treat cryptococcal meningitis in the Eastern Cape Province of South Africa [64]. Moreover, a 2 log reduction in feline herspesvirus type 1 growth was discovered [59].

Rapanea melanophloeos is a medicinal plant used by Zulu traditional healers to manage blood-clot related diseases [65]. Various extracts (methanol, n-hexane, chloroform, ethyl acetate and aqueous) prepared from the bark of Rapanea melanophloeos were screened for phytochemicals as well as antioxidant and anti-platelet aggregation activity. Phytochemical screening of this plant showed the presence of tannins, terpenoids, alkaloids, saponins, cardiac glycosides, flavonoids and phlobatannins [65]. The traditional use of Rapanea melanophloeos by South Africans in curing TB-related symptoms such as fever, cough, chest disease, night sweats etc. has been reported [53]. This plant is traditionally used in Kenya to reduce parasitism in small ruminants [66]. Sakurasaponin was isolated from the methanolic leaf extract of Rapanea melanophloeos and was found to be active against Cladosporium cucumerinum [67]. However, in the domain of influenza disease management where there are annual epidemic burdens and fatal pandemics from time to time, there has been no study of any of the above-mentioned plants for their effect against IAV so far. In this study, we evaluated the antiviral activity of extracts of these plants against influenza A virus infection. Unfortunately, the extracts $1,7,8$, and 10 which were obtained from hot and cold aqueous and 30\% ethanol of Pittosporum viridiflorum and Cussonia spicata did not dissolve well in DMSO as the consistent solvent used and they were removed from the experiment.

\section{Conclusions}

Medicinal plants used for treating various disorders may have useful biological activities, particularly against infectious diseases. Crude plant extracts contain a diversity of constituents that may exert their antiviral effect either alone or as synergistic effects of compounds together. In this study, based on the evaluation of antiviral results, only 5 extracts [methanol extract of Rapanea melanophloeos and 100\% and 30\% ethanol, methanol and acetone extracts of Pittosporum viridiflorum] were selected for further evaluation. These plants may have the capacity to ease the symptoms of flu. However, no scientific research has been conducted previously to validate the antiviral activity of these plant species. The fact that some degree of inhibition was observed with these extracts may suggest that the extracts contain active component(s) that may be responsible for the observed anti-influenza activity. The next focus of this study will be the isolation and characterization of compounds responsible for bioactivity against IAV infection as well as their mode of action.

\section{Additional files}

Additional file 1: Figure S1. Estimated Marginal Means of Log HA titer. This graph shows the Log HA titer levels analyzed by GLM. (TIF 51 kb)

Additional file 2: Figure S2. Estimated Marginal Means of Log HA decrement. This graph shows the decrement levels in Log HA titers analyzed by GLM. (TIF 50 kb)

Additional file 3: Figure S3. Estimated Marginal Means of cell viability. This graph shows the ODs of the cell viability test analyzed by GLM. (TIF $53 \mathrm{~kb}$ )

Additional file 4: Figure S4. Estimated Marginal Means of percentage of protection. This graph shows the protection of the extracts on the cell viability analyzed by GLM. (TIF $56 \mathrm{~kb}$ )

\section{Abbreviations}

ANOVA: Analysis of variance; $\mathrm{CC}_{50}$ : $50 \%$ cytotoxic concentration; $\mathrm{CCID}_{50}$ : Cell culture infectious dose 50; CEF: Chloroform: Ethyl acetate: Formic acid; CRBCs: Chicken red blood cells; DMEM: Dulbecco's Modified Eagle's Medium; $\mathrm{EC}_{50}$ : 50\% effective concentration; EMW: Ethyl acetate: Methanol: Water; FBS: Fetal Bovine Serum; GLM: General linear model; HA: Hemagglutination assay; HI: Hemagglutination inhibition assay; IAV: Influenza A virus; MDCK: Madin Darby Canine Kidney; MTT: [3-(4,5-dimethyl-2-thiazolyl)-2,5diphenyl-2H-tetrazolium bromide]; OD: Optical density; SI: Selectivity index; TLC: Thin layer chromatography; Trypsin-TPCK: Tosylamide Phenylethyl Chloromethyl Keton-treated Trypsin

\section{Acknowledgements}

Our sincere gratitude to the laboratory of Vaccine and Immunotherapeutics, Institute of Bioscience, Universiti Putra Malaysia; Prof Dr. Aini Ideris and Prof Dr. Abdul Rahman Omar who kindly provided amantadine hydrochloride and oseltamivir carboxylate.

\section{Funding}

This study was supported by the National Research Foundation under the cost center number N00882, project 98033RUN, South Africa. The funder had no involvement in the collection, analysis and interpretation of data; writing of the report; and the decision to submit the article for publication. 


\section{Availability of data and materials}

The datasets used and/or analyzed during the current study are available from the corresponding author on reasonable request.

\section{Authors' contributions}

PM, FOF, LJM co-defined the research theme. PM designed the methods and experiments. JNE, LM provided the facilities of the Phytomedicine Laboratory. FF, BF1 provided the facilities for antiviral work. PM carried out the laboratory experiments in collaboration with ASA, EMN, MAA, DAG, MT, OGF. PM analyzed the data and drafted the manuscript. PM, MAA co-worked on the associated data collection and their interpretation. PM, MAA, EMN, LM, JNE, FOF revised the manuscript critically for editorial and important intellectual content. All authors have seen and approved the manuscript.

\section{Ethics approval and consent to participate}

Not applicable

\section{Consent for publication}

Not applicable

\section{Competing interests}

The authors declare that they have no competing interests. Prof Jacobus N Eloff is a section editor and Prof Lyndy J McGaw is an associate editor of BMC Complementary and Alternative medicine.

\section{Publisher's Note}

Springer Nature remains neutral with regard to jurisdictional claims in published maps and institutional affiliations.

\section{Author details}

'Department of Veterinary Tropical Diseases, University of Pretoria, Pretoria, South Africa. ${ }^{2}$ Influenza and Other Respiratory Viruses Department, Pasteur Institute of IRAN, Tehran, Iran. ${ }^{3}$ Phytomedicine Programme, Department of Paraclinical Sciences, University of Pretoria, Pretoria, South Africa. ${ }^{4}$ Federal Institute of Industrial Research, Oshodi, Lagos, Nigeria. ${ }^{5}$ Department of Production Animal Studies, University of Pretoria, Pretoria, South Africa. ${ }^{6}$ Department of Animal Health, Federal College of Animal Health and Production Technology, Ibadan, Nigeria. ${ }^{7}$ ECTAD, Food and Agriculture Organization of the United Nations (FAO), Block P, Level 3, United Nations Complex, UN Avenue, Gigiri, Nairobi, Kenya.

\section{Received: 22 June 2017 Accepted: 22 March 2018}

\section{Published online: 27 March 2018}

\section{References}

1. Rajasekaran D, Palombo EA, Chia Yeo T, Lim Siok Ley D, Lee Tu C, Malherbe $F$, et al. Identification of traditional medicinal plant extracts with novel antiinfluenza activity. PLoS One. 2013;8:e79293.

2. Webster R, Bean WGO, Chambers T, Kawaoka Y. Evolution and ecology of influenza a viruses. Microbiol Rev. 1992;56:152-79.

3. Hilleman M. Realities and enigmas of human viral influenza: pathogenesis, epidemiology and control. Vaccine. 2002;20:3068-87.

4. Whitley RJ, Monto AS. Prevention and treatment of influenza in high-risk groups: children, pregnant women, immunocompromised hosts, and nursing home residents. J Infect Dis. 2006;194:S133-8.

5. Ison MG. Antivirals and resistance: influenza virus. Curr Opin Virol. 2011;1: 563-73

6. Fedson DS. Confronting an influenza pandemic with inexpensive generic agents: can it be done? Lancet Infect Dis. 2008;8:571-6.

7. Pathumwadee I, Chittima L, Thanyada R, Arthorn L, Maturos M, Panita D, et al. How amantadine and rimantadine inhibit proton transport in the M2 protein channel. J Mol Graph Model. 2008;27:342-8.

8. Beringer P, Troy A, David A, Remington JP. The science and practice of pharmacy. Philadelphia: Lippincott Williams \& Wilkins; 2006. p. 1419

9. Sarah CD, Hong M. Amantadine-induced conformational and dynamical changes of the influenza M2 transmembrane proton channel. P Natl Acad Sci USA. 2008;105:1483-8.

10. Rodriguez WJ, Hall CB, Welliver R, Simoes EA, Ryan ME, Stutman H, et al. Efficacy and safety of aerosolized ribavirin in young children hospitalized with influenza: a double-blind, multicenter, placebo-controlled trial. J Pediatr. 1994;125:129-35.
11. Khalafalla MM, Abdellatef E, Dafalla HM, Nassrallah AA, Aboul-Enein KM, Lightfoot DA, et al. Active principle from moringa oleifera lam leaves effective against two leukemias and a hepatocarcinoma. Afr J Biotechnol. 2010:9:8467-71.

12. Gurib-Fakim A, Brendler T, Philips LD, Eloff JN. Green gold: success stories using southern African medicinal plant species. Devon: AAMPS Publishing; 2010

13. Chang-Xiao L. Development of Chinese medicine based on pharmacology and therapeutics. J Ethnopharmacol. 1987;19:119-23.

14. Belachew D. Ethiopian traditional herbal drugs. Part II: antimicrobial activity of 63 medicinal plants. J Ethnopharmacol. 1993;39:129-39.

15. Anesini C, Perez C. Screening of plants used in argentine folk medicine for antimicrobial activity. J Ethnopharmacol. 1993;39:119-28.

16. André N, Topul R, Otto S. Biological screening of traditional medicinal plants from Papua New Guinea. J Ethnopharmacol. 1995;49:147-56.

17. Amic D, Amie DD, Beslo D, Trinajstic N. Structural-radical scavenging activity relationship of flavonoids. Croat Chem Acta. 2003;76:55-61.

18. Aqil F, Ahmad I, Mehmood Z. Antioxidant and free radical scavenging properties of twelve traditionally used Indian medicinal plants. Turk J Biol. 2006;30:177-83.

19. Louw CAM, Regnier TJC, Korsten L. Medicinal bulbous plants of South Africa and their traditional relevance in the control of infectious diseases. $J$ Ethnopharmacol. 2002;82:147-54.

20. Van wyk BE, Gericke N. People's plants. A guide to useful plants of southern Africa. Pretoria: Briza Publications; 2000

21. Street RA, Prinsloo G. Commercially important medicinal plants of South Africa: a review. J Chem. 2013;2013:16.

22. Tomohiro K, Hidekazu N. Antipyretic effect of Mao-to, a Japanese herbal medicine, for treatment of type a influenza infection in children. J Phytomed. 2006;30:17141491.

23. Park KJ. Evaluation of in vitro antiviral activity in methanol extracts against influenza virus type a from Korean medicinal plants. Phytother Res. 2003;17: 1059-63.

24. Wei B, Cha SY, Kang M, Kim YJ, Cho CW, Rhee YK, et al. Antiviral activity of Chongkukjang extracts against influenza a virus in vitro and in vivo. J Ethnic Food. 2015:2:47-51.

25. He W, Han H, Wang W, Gao B. Anti-influenza virus effect of aqueous extracts from dandelion. Virol J. 2011:8:538.

26. Van Wyk B, Van Wyk P. Field guide to trees of southern Africa. South Africa: Struik; 1997.

27. Jager AK, Hutchings A, Van Staden J. Screening of Zulu medicinal plants for prostaglandin-synthesis inhibitors. J Ethnopharmacol. 1996;52:95-100.

28. McGaw LJ, Jager AK, Van Staden J. Antibacterial, anthelmintic and antiamoebic activity in south African medicinal plants. J Ethnopharmacol. 2000; 72:247-63.

29. Luseba D, Elgorashi EE, Ntloedibe DT, Van Staden J. Antibacterial, antiinflammatory and mutagenic effects of some medicinal plants used in South Africa for the treatment of wounds and retained placenta in livestock. S Afr J Bot. 2007:73:378-83.

30. McGaw LJ, Van der Merwe D, Eloff JN. In vitro anthelmintic, antibacterial and cytotoxic effects of extracts from plants used in south African ethnoveterinary medicine. Vet J. 2007;173:366-72.

31. Kraft C, Jenett-Siems K, Siems K, Jakupovic J, Mavi S, Bienzle U, et al. In vitro antiplasmodial evaluation of medicinal plants from Zimbabwe. Phytother Res. 2003;17:123-8.

32. Mbeng Otang W, Scott Grierson D, Ndip Ndip R. Phytochemical studies and antioxidant activity of two south African medicinal plants traditionally used for the management of opportunistic fungal infections in HIV/AIDS patients. BMC Complement Altern Med. 2012;12:43.

33. Thabile L. Compounds from rapanea melanophloeos (L.) Mez. 2012.

34. Karber G. 50\% endpoint calculation. Arch Exp Pathol Pharmacol. 1931;162: $480-3$.

35. Mehrbod P, Ideris A, Omar AR, Hair-Bejo M. Evaluation of antiviral effect of atorvastatin on H1N1 infection in MDCK cells. Afr J Microbiol Res. 2012;6: 5715-9.

36. Mosmann T. Rapid colorimetric assay for cellular growth and survival: application to proliferation and cytotoxicity assays. J Immunol Method. 1983:65:55-63.

37. Mehrbod P, Motamed N, Tabatabaian M, Soleimani-Estyar R, Amini E, Shahidi $M$, et al. In vitro antiviral effect of "Nanosilver" on influenza virus. Daru. 2009;17:88-93. 
38. Chattopadhyay D, Sarkar MC, Chatterjee T, Sharma Dey R, Bag P, Chakraborti $\mathrm{S}$, et al. Recent advancements for the evaluation of anti-viral activities of natural products. New Biotechnol. 2009;25:347-68.

39. Shigeta S, Shuichi M, Junko W, Shu S, Kauzo T, Yamase T. Synergistic antiinfluenza virus a (H1N1) activities of PM-523 (Polyoxomatalate) and ribavirin in vitro and in vivo. Antimicrob Agents Ch. 1997:41:423-1427.

40. Hirst GK. The quantitative determination of influenza virus and antibodies by means of red cell agglutination. J Exp Med. 1942;75:49-64.

41. Kotzé M, Eloff JN. Extraction of antibacterial compounds from Combretum microphyllum (Combretaceae). S Afr J Bot. 2002;68:62-7.

42. Cos P, Vlietinck PC, Vanden Berghe AJD, Maes L. Anti-infective potential of natural products: how to develop a stronger in vitro 'proof-of concept'. J Ethnopharmacol. 2006;106:290-302.

43. Camargo F, Cortez DA, Ueda-N. T, Nakamura CV, Dias Filho BP. Antiviral activity and mode of action of a peptide isolated from Sorghum bicolor. Phytomedicine. 2008;15:202-8.

44. Choi HJ, Lim CH, Song JH, Baek SH, Kwon DH. Antiviral activity of raoulic acid from Raoulia australis against picornaviruses. Phytomedicine. 2009;16:35-9.

45. Mehrbod P, Ideris A, Omar AR, Hair-Bejo M, Tan SW, Kheiri MT, et al, Attenuation of influenza virus infectivity with herbal-marine compound (HESA-A): an in vitro study in MDCK cells. Virol J. 2012;9:44.

46. Hayden FG, de Jong MD. Emerging influenza antiviral resistance threats. J Infect Dis. 2011;203:6-10.

47. Cheng PKC, Leung TWC, Ho ECM, Leung PCK, Ng AYY, Lai MYY, et al. Oseltamivir- and amantadine-resistant influenza viruses a (H1N1), Emerg infect. Diseases. 2009;15:966-8.

48. Rothberg MB, Haessler SD. Complications of seasonal and pandemic influenza. Crit Care Med. 2010;38:e91-7.

49. De Jong MD, Simmons CP, Thanh T, Hien VM, Smith GJ, Chau TN, et al. Fatal outcome of human influenza a $(\mathrm{H} 5 \mathrm{~N} 1)$ is associated with high viral load and hypercytokinemia. Nat Med. 2006;12:1203-7.

50. Lippi G, Franchini M. Influenza and cardiovascular disease: does swineorigin, 2009 H1N1 flu virus represent a risk factor, an acute trigger, or both? Semin Thromb Hemost. 2010;36:49-58.

51. To KKW, Hung IFN, Li IWS, Lee KL, Koo CK, Yan WW, et al. Delayed clearance of viral load and marked cytokine activation in severe cases of pandemic H1N1 2009 influenza virus infection. Clin Infect Dis. 2010;50:850-9.

52. Fedson DS. Pandemic influenza: a potential role for statins in treatment and prophylaxis. Clin Infect Dis. 2006;43:199-205.

53. Watt JM, Breyer-Brandwijk MG. The medicinal and poisonous plants of southern and eastern Africa. 2nd ed. Edinburg: E. \& S. Livingstone; 1962.

54. Hutchings A, Scott AH, Lewis G, Cunningham A. Zulu medicinal plants: an inventory. 1st ed. South Africa: University of Natal Press; 1996.

55. von Koenen E. Medicinal, poisonous, and edible plants in Namibia. 4th ed. Windhoek: Klaus Hess Publishers; 2001.

56. Clarkson C, Maharaj VJ, Crouch NR, Grace OM, Pillay P, Matsabisa MG, et al. In vitro antiplasmodial activity of medicinal plants native to or naturalised in South Africa. J Ethnopharmacol. 2004;92:177-91.

57. Masevhe NA, Awouafack MD, Ahmed AS, McGaw $\sqcup$, Eloff JN. Clerodendrumic acid, a new triterpenoid from Clerodendrum glabrum (Verbenaceae), and antimicrobial activities of fractions and constituents. Helv. 2013;96:1693-703.

58. Adamu M, Naidoo V, Eloff JN. The antibacterial activity, antioxidant activity and selectivity index of leaf extracts of thirteen south African tree species used in ethnoveterinary medicine to treat helminth infections. BMC Vet Res. 2014;10:52.

59. McGaw LJ, Bagla VP, Mokoka TA, Elgorashi EE, Eloff JN. South African ethnoveterinary plant extracts with antimicrobial and antiviral potential. Abstracts of the world congress on medicinal and aromatic plants, Cape Town. Afr J Tradit Complement Altern Med. 2008;6(Supplement):472.

60. Toovey S. Influenza-associated central nervous system dysfunction: a literature review. Travel Med Infect Dis. 2008;6:114-24.

61. Studahl M. Influenza virus and CNS manifestations. J Clin Virol. 2003;28:225-32.

62. Oda T, Akaike T, Hamamoto T, Suzuki F, Hirano T, Maeda H. Oxygen radicals in influenza-induced pathogenesis and treatment with pyran polymerconjugated SOD. Science. 1989;244:974.

63. $\amalg$ MG. Evaluation of anthelmintic, antiamoebic and antibacterial activity in traditional South African medicinal plants. School of Botany and Zoology. Vol. Doctor of Philosophy. Pietermaritzburg: University of Natal; 2001. p. 174.

64. Otang WM, Grierson DS, Ndip RN. Phytochemical studies and antioxidant activity of two south African medicinal plants traditionally used for the management of opportunistic fungal infections in HIV/AIDS patients. BMC Complement Altern Med. 2012;12:43.

65. Gwala PE. Anti-platelet aggregation activity of Rapanea melanophloeos -A Zulu medicinal plant. Department of Biochemistry and Microbioogy. Vol. Master of Science. University of Zululand. 111 pages, 2011.

66. Githiori JB, Höglund J, Waller PJ, Baker RL. Anthelmintic activity of preparations derived from Myrsine africana and Rapanea melanophloeos against the nematode parasite, Haemonchus contortus, of sheep. J Ethnopharmacol. 2002:80:187-91.

67. Ramavhoya MR. Chemical and biological properties of euphorbia ingens $E$. Mey Faculty of Health Sciences, School of Pharmacy (Pharmaceutical Chemistry) Vol. Master of Science. North-West University (Potchefstroom campus) 72 pages, 2005

\section{Submit your next manuscript to BioMed Central and we will help you at every step:}

- We accept pre-submission inquiries

- Our selector tool helps you to find the most relevant journal

- We provide round the clock customer support

- Convenient online submission

- Thorough peer review

- Inclusion in PubMed and all major indexing services

- Maximum visibility for your research

Submit your manuscript at www.biomedcentral.com/submit
) Biomed Central 